\title{
Economic Obsession in Early Literary Imagination: Shakespeare, Jonson and More ${ }^{1}$
}

\author{
FRANCIS K. H. SO
}

\begin{abstract}
That revenues, profits, wealth, valuables, properties and various forms of riches can be so attractive to most people is because these resources affect the operational mode of social economy and personal well-being. As a major driving force of social development, the desire to accumulate wealth affords people the prospect of leading a comfortable life. Yet the acquisition of which may bring down other people to become poorer and creating potential social injustice. Three interrelated concepts in money spending: consumption, fear of poverty and social justice/injustice are markedly shown in some of the great minds among English writers.
\end{abstract}

In this article, Shakespeare's The Merchant of Venice, Ben Jonson's Volpo$n e$ and Thomas More's Utopia are used to demonstrate the concerns of the early modern English mentality. Some scholars have suggested that the first two playwrights reflected the fear that their London would come to be ruled by corruption, swindling, greediness, vicious competition and unethical business practices. In this pre-capitalist economy, people are seen to adopt unfair competition and reciprocal malice in order to accumulate wealth. Entrepreneurial liberation in economic affairs sets off the dark side of humanity in which the playwrights were most probably implicated.

To counteract this rapacious thinking, Thomas More offers his conception of a wealthy and happy worldly life. Not to attack the self-centered, benefit gaining intentions, Utopia builds up a society that claims fairness, commonwealth, more obligations than privileges and the wiping away of vanity. Mercantilism is not denied, yet private property is contained. Written earliest among the three works, Utopia anticipates the two plays that dwell on social evils sparked by over concern for personal gains.

Generally, the three works lay the foundation of positive and negative aspects of economy in terms of production, marketing, circulation, consumption and services of the English mind of that era. The social mood borders on the financial and political matters of the bourgeois class while providing

1 An early draft of this paper was presented as an invited speaker's paper at the 2016 English Language and Literature Association of Korea International Conference, Daejeon, Korea, December 13-15.

DOI: https://doi.org/10.12697/IL.2019.24.1.6 
a mega-worldview as well as micro-worldview of economic concern of the sixteenth and seventeenth centuries England.

Keywords: economic concerns; mentality; William Shakespeare; Ben Jonson; Thomas More

At the start of the sixteenth century, England had already bidden farewell to the Middle Ages, introducing a relatively harmonized Tudor period. This means, among other things, England needed to develop its economy for a stabilized society free from strife of civil wars and plagues. The "bastard feudalism" (Elton 1997: 3-9) had been broken down. From all sides, particularly at the grassroots level, there was strong awareness that "the king 'should live of his own' - that is, on his regular revenue and without recourse to special grants" (Elton 1997: 48). Inevitably this brought about the idea of self-sustaining and self-sufficient economic means among all classes as people desired to have enough money to spend and as little tax to pay as possible. Revenues, profits, justice, and survival means are as applicable to the ordinary people as to the king. A dependable source of income will bring stability and assurance, guaranteeing individual well-being as well as national security.

It was in that overall mood that Thomas More wrote his Utopia (1516) in Latin intending to reach the learned intellectuals who would contribute to and help shape up government policies. The work was circulated internationally in no time. Radical or liberal, he offers a meaningful egalitarianism. Soon an English text of the Utopia (1551) becomes a necessity, either for its demand for hopes or for providing spiritual bread to a growing reading public. With Plato's Republic in the backdrop, More as a forerunner of humanism lay out his blue print of a land of justice. It brings forth immediately a politico-economic realm that is non-existent and yet desirable. Though the book is heavily dosed with socialism and an ideal form of communism, the realities thus presented appeared to be fantastic if not too good to be true. Such a social mode has been commented on as impracticable from an economic point of view, for

[a] key element in all human progress is the growth of knowledge. Yet it is precisely on this issue that the polar utopias of socialism and market individualism have foundered. Socialism has neglected the enormous problems of gathering together all relevant knowledge in the service of an overall plan. Market individualism has neglected learning and the growth of knowledge by assuming that the individual somehow always knows now what is in his or her best interest in the future. It is assumed that the individual acquires knowledge but is somehow unchanged in the process. (Hodgson 1999: 11) 
On that basis, Hodgson argues that genuine economics has to go beyond utopia. But More's utopian commonwealth economy really does not deny the application of knowledge or go against mercantilism; it only adopts the monastic practice of holding no private properties. At the same time it intends to cut off hereditary privileges that Pierre Bourdieu would label as cultural capital (Bourdieu 1986: 241-258). The latter condition belongs to market economics or rather capitalism which will perpetuate classes despite individual efforts to transcend them. On that count, More emphasizes education and social mobility so that there are opportunities to break up hierarchical classes and to contain aristocratic privileges. More does not like superficial justice or justice that engenders violence. In a nutshell, he is in favor of "[restricting] the right of the rich to buy up anything and everything, and then to exercise a kind of monopoly. Let fewer people be brought up in idleness. Let agriculture be restored and the wool manufacture revived as an honest trade, so there will be useful work for the whole crowd of those now idle - whether those whom poverty has already made into thieves, or those whom vagabondage and habits of lazy service are converting, just as surely, into the robbers of the future" (Utopia, Book 1, 20-21). Obviously More's sense of national economy is an opportunity for the largest possible population who can benefit from decent work contributing to their physical as well as spiritual well-being. That means each able body will have work to do and there will be no idleness and unemployed vagabonds. As a trained lawyer, More would have known of the Vagabonds and Beggars Act of 1494 that aimed to punish the poor simply because they were deprived. In fact, the problem of the vagabonds, or vagrants, roaming from town to town in search of work and financial relief was so irritating that in 1536 vagabonds when caught were to be whipped and by the end of the century it was legal to hang them (Slack 1988: 94). Thus jobs for the poor will on the one hand eliminate idlers and structural poverty and on the other hand reduce vagabonds or crimes on the street. After the War of the Roses, sixteenth-century agriculture did require a steady supply of laborers and the shortage of which would hurt production and ultimately the price of grain. Also, agricultural products are vital foodstuff and commodities that sustain human life. In that sense, proper employment opportunities in agriculture are basic for sustenance and they do more good than appear on the surface. To maximize that every person has a niche to enjoy social development, two typical forms of the English economy, agriculture and the wool trade, answer that call. In particular, agriculture which is labor intensive engages the Utopians to "produce much more grain and cattle than they need for themselves, and share the surplus with their neighbors. Whatever goods the folk in the country need which cannot be produced there, they request of the 
SO

town magistrates, and since there is nothing to be paid or exchanged, they get what they want without any trouble" (Book 2, 41). What these lines indicate is that sufficient supplies of food and goods mean a good way to get rid of the anxiety of destitution and merciful reliance on the English lords. People there do not worry about overproduction because a price drop that hurts the farmers has not been an issue in that land. If anything, More actually witnesses price increase of goods due to an "imbalance between the growth of population and agricultural output" (Outhwaite 1982: 50) in England at the time and the phenomenon extended well into the seventeenth century.

Besides, the surplus production not only gives the residents a safety margin which is an idea of saving for the rainy days, but also a notion of sharing - a true communal spirit. In fact, surplus supplies have to be considered a form of currency without minting coins. The practice is an early form of building up monetary credit or accumulation of capital without going through the banking system. This makes up an integrated and accountable system of labor - production - application or marketing - circulation - distribution and storing and retrieval. There is a total absence of manipulation or exploitation of the middlemen, much in tune with Marxist economic thinking. Yet, proper commercial activities are encouraged while monopoly - remnant of the aristocratic privilege is to be curtailed. In More's England, monopoly brought forth unjust enrichment of a limited few and the situation stayed on since those monopolies, like feudal titles, were hereditary. The utopian system definitely intends to get rid of them.

In addition, More is mindful of having "the wool manufacture revived as an honest trade." The upstream of the wool manufacturing is farming, an offshoot of agriculture. But the Anti-Enclosure Acts from 1489 signaled that enclosure of commons land was already a social problem and common people had less grazing acreage to continue cattle farming. Putting a cap on the landowners' prerogative would help the commoners and farm production. Yet the downstream product would not contribute well to the English economy unless the demand for wool could expand to become international consumption. For that matter, most of the English wool had to be shipped to Antwerp to make into wool cloth. Not only does the wool business need to be a trade, it has to be an "honest trade." When asserting the word "honest" More expects the traders and merchants to be decent businessmen and not profiteers. After production, marketing and sales would enhance the product's added value and create even more employment opportunities for the workers. How much industrialization is involved may not be the concern of More's utopian economy, but specific forms of labor and production that were geared toward special kind of agricultural 
capitalism and international trade surely occupy More's thinking. This is not one-sided or self-centered thinking; rather it is the combination of production with trade (i.e., marketing, shipping, circulation and dissemination of goods) to form a macro-economic equilibrium that affects good living of the people. It is More's way of getting rid of poverty, generating self-worth through tangible labor and social role, reducing class tension and gaining human dignity. If More is obsessed by his dream-like utopia, it is all because he has such esteem for humanity and social justice. Nevertheless, the Utopians not only experience an active life as against the monastic contemplative life for the benefits of the working class, there is also forced labor in the commonwealth. His economic thinking is tied up to political formation of society. But the good thing about it is that there is fair distribution of wealth and desires for wealth are scorned. To ensure such social economy to function smoothly residents of the realm would have to have active and meaningful involvement in politics. Though there are classes in this society there is no class struggle or purges that featured in latter day communism. People essentially find the hopeful nature of commonwealth and pleasure. With the populace in mind More has dynamically engineered an epoch-making socio-political economy.

Indeed, the early modern period confronted these establishments as England experienced a time of inflation and rapid population growth that incurred a widening gap between the wealthy and the poor. The English population in the 1520 's was about 2.3 million, increased to nearly 3 million in 1551, and to almost 4 million by 1601 (Clay 1984: 4). Jobs for the idlers became an imminent and accountable social issue. Setting up work for everyone in Utopia is visionary and far-sighted. Besides, from the first quarter of the sixteenth century, prices rose $400 \%$ by the end of the sixteenth century (Heard 1992: 25) due to shortage of supply of goods and foodstuffs. Other computation puts inflation of the Tudor period as: "Between 1500 and 1540 prices rose by a half; they then more than doubled in the next twenty years; thereafter the curve flattened, but by the end of the century prices were about five and a half times what they had been 100 years earlier" (Elton 1997: 221-222). These social pressures and changes caused a disruption in the natural order of society: the idea that every man, woman, and child knew his or her place in the English society. With the implementation of Utopia, "the king should live of his own" and should behave like his subordinates to be self-sustaining would only be a fair game in the minds of the people.

In a sense Utopia has made a communal bond with its citizens that everyone is guaranteed with a job and provided with proper social welfare that will not default. Through their conscientious labor, citizens have in good faith entered 
SO

into an unwritten contract with the state, the former being the creditor and the latter debtor. But if socialism is a state-owned credit-debit system, capitalism then works on an individual basis and each person will have to be responsible for his or her own financial planning, including loan and debt. In essence, More's Utopia bears witness to the notion that productivity of labor determines social prosperity. In that light, Shakespeare's The Merchant of Venice stands in strong contrast to More's Utopia in terms of productivity, contractual warranty and lifestyles that reflect another type of economic system that deals with money-lending mechanism.

Though officially prohibited and condemned by the church, usury was a common financial practice in Elizabethan England. The royal merchant Antonio who generously helps other Christians when they moan to him considers Shylock a "usurer" (3.1.48). How high an interest Shylock charges for his money lending is not known in the story. Yet in 1545 England enacted "An Act Against Usurie" (37H. viii9) and reaffirmed in a 1571 statute to put a cap on the interest that money lenders could charge and hence it became legal to charge interest on loans (Kennard \& Hanne 2015: 249). Because of that Act apart from the increase of available capital, short-term interest rate dropped from the $20-30 \%$ mark to $9-10 \%$ level (ibid. 250). On the basis of that data, if Shylock was charging the maximum $20-30 \%$ rate, he was making similar to the present day credit card or cash advance loan rate considering the high inflation at the time. Yet people today, feeling however uncomfortable, will not call the credit card company usurers. But one indicator of the shocking inflation in the sixteenth century was that between 1526 and 1551, coinage debasement rendered money worth one quarter of the original and this matched up with the contemporary inflation situation. Though Bassanio's loan was for a short period of three months, the time factor plus other considerations would cause the money-lender to charge a high rate during that era. Shylock's risks (without receiving sureties or collaterals) by charging high usury were actually a common practice of merchants. The loan was initiated because Bassanio wanted to compete with the rich princes when approaching Portia. Had he toned down his choice of apparel and gifts he would not act as what Shylock labelled as the "prodigal Christian" (2.5.15). Needless to say he might not need the 3000-ducat loan. But the loan would uplift him with stylish dress and becoming looks that would accord him with compatible social mobility. These are means for Bassanio to acquire power and status, another form of cultural capital. Yet, the apparent luxury and vanity get him into financial trouble. His loan has nothing to do with labor productivity or generating prosperity. Additionally, the three major characters in the incident, Shylock, Bassanio and 
Antonio, whether in Venice or in London, make up two contrastive attitudes toward wealth and lifestyle. Shylock enjoys a self-sufficient life and is on the surplus side that enables him to lend out money to those who need it. Antonio though rich is cash tight because his investments - four shiploads of goods have tied him down without much cash flow. As to Bassanio, he needs to borrow money to put up an affluent front. Not being the underprivileged, he has overextended his credit. He serves as the driving force of consumption and consumerism. To the financial conservatives, he sets a bad example. Yet, without people like him, there will be little demand for expensive consumer products and luxury items will have few outlets. In that connection, while asserting his individual rights of leading an expensive lifestyle, by paying the proper price, Bassanio represents some core value of capitalism. He drums up demand for the capital market.

Compared with Utopia, Venice trades luxurious goods and creates high quality type of services and entertainments. Typically, Venice signifies a business world promoting open competition while Utopia a work-induced world though pleasure has not been neglected. To maintain proper order of conducting business, agreements, contracts and laws are the inevitable means of mechanisms to protect all parties involved. Conscionable or not, the agreements or bonds among different business parties are to be notarized for warranty sake such that Shylock will tell Antonio that

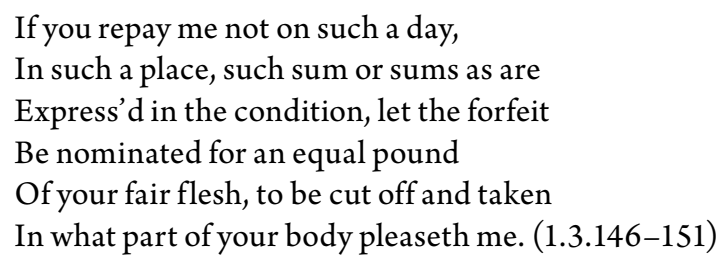

It is interesting to note is that Shylock does not spell out the total amount of repayment. That is to say, we have no way to ascertain how much interest he charges. The only clue we have is that Antonio is bonded and that one pound of his flesh will be cut off from his body if he fails to pay back the loan on time. Since the case has been notarized, Bassanio, Antonio and Shylock are bound by contract law. Though the penalty reimbursement sounds silly and unreasonable, Antonio does not worry about its consequence. In fact, he has full confidence that he will manage. Though his merchandise carrier ships are on the sea, they will come back in two months with extremely lucrative profits, with "return of thrice three times the value of this bond" (1.3.158-159). Commercial risks aside, this nine-fold yield of profit is exorbitantly high. It 
typifies the exploitive nature of capitalism gained by merchants. Eventually when it is known that Antonio lost his ships and thus was liable to be charged with a pound of his flesh, Portia advised Bassanio to pay Shylock "six thousand, and deface the bond" (3.2.299). The suggested figure clearly indicates that the interest Shylock charges is much less than $100 \%$. Now, if Antonio's profit margins are $900 \%$ it means that his harvest is unreasonably high. When a $30 \%$ interest usury is branded bad, $900 \%$ exploitation trading is worse. The only difference between the two modes of business transaction signifies that Shylock reaps profits without doing much work whereas Antonio pockets his gains by doing some buying and selling involving risks at high seas. Both kinds are investments by helping those who need money or the commodities. If charging 30\% interest is considered usury, how should one label a $900 \%$ yield? Evidently there is double standard. Complicating the situation is that one is a Jewish businessman while the other is a Christian merchant. The temptation of a $900 \%$ Christian profit margin actually supports the practice of a $30 \%$ Jewish interest with the implication that decent and needy businessmen are the promoters of the $30 \%$ interest usury. Nevertheless, Antonio does not feel that he has been doing unjust business though he ordinarily will "lend money for a Christian cur'sy [courtesy]" (3.1.49), i.e., he "lends out money gratis" (1.3.44).

Generally considered nasty and a social ill, usury is being scorned at but it claims certain necessities. Yet whether the loan shark is called Shylock or Antonio or any other name who is a Christian, such an act remains contemptible. But if the loan charges a moderate rate the money-lending act will provide dire need to those who have to depend on the turnover capital. In this situation, or rather Venice allegorized as the rising London, money-lending with the intention to help running businesses is pitting against maritime trade that apparently is exploitive. When the import goods are expensive, they will raise the prices of peripheral categories and indirectly jack up market prices in general. Helping needy businessmen on the one hand but exploiting the common people on the other sounds contradictory and hypocritical. While More's society pays more attention to production for which most societies depend on, Shakespeare's Venice keeps a close eye on consumption and issues evolving from it. Shylock's dealings, in particular, hardly generate any hard-core labor that factors into substantive production. They only promote consumer demands and contribute little to industrialization for which labor will become more vital. Shylock is blamed for benefiting no labor pool and labor power though in fact he is attempting to service an early form of banking. Comparatively, Antonio's investment is considered respectable for supporting the Venetian outward bound exploration of sea power and transferring riches 
from afar while offering employment opportunities to the ship building, shipping, import, export and related industries. One finds in More's society artisans prevail while in Venice merchants surface. But among merchants, they are sub-divided into several kinds, some lovable and some detestable, some purely money-chasing, some underwriters such as Tubal (3.1.57-58), and other more or less industrialized type of financing.

It may be ambivalent to classify the category of merchant Antonio belongs to because the social mood of the time can have different kinds of interpretations. If a $900 \%$ profit at the time is justified and acceptable, Antonio certainly can be said a good and successful businessman. His enterprise is based on a free market with open competition that requires first of all accumulation of capital and statesanctioned act of transaction or social policies. The Utopian manorial-like labor is now shifted to becoming the Antonio type of seafarers' labor that produces. However enterprising, Antonio will not be considered a decent gentleman if he does not combine his commodity exchange with investment of capital that benefits the shipping industry when conducting this high risk maritime trade. Because of the risk he is handsomely rewarded but his eventual accumulation of riches may mean the extortion of other people's income and resource. He will enjoy an extremely comfortable living standard at the depletion of other people's wealth. In this capital intensive world, wealth and riches do not belong to those who make it work through their labor but to those who can manipulate their own capital or other people's revenues. Growth of capital that makes Antonio socially distinguished depends on trade with exclusive rights and rewards that are far better than terms of usury. Conditions of mercantilism include wide indulgence of foreign trade, giving it the very lucrative gains. At the same time, the social infrastructure includes providing law protection to the merchant class with which Shylock applies for his own good.

When Antonio loses his life investments in the sunken ships he is faced with the consequent demand for payment of his own pound of flesh. Shylock the creditor will not give up the claim despite being offered with better monetary terms than his loan of kindness. This money-based economy now turns to legal entanglement for which the duke in Venice is approached for arbitration. Yet, as admitted by Antonio, even

The duke cannot deny the course of law:

For the commodity that strangers have

With us in Venice, if it be denied,

Will much impeach the justice of his state;

Since that the trade and profit of the city

Consisteth of all nations. (3.3.26-31) 
SO

Though marginalized and despised, the moneylenders Shylock and his kind will enjoy equitable status under the same protective law since his contract with Antonio has been bonded just as Antonio is permitted to collect his aggrandized commercial profits because he is sheltered by the same law. That contractual law when planned to be part of the "cosmopolitical economies" (Sokol \& Sokol 1999: 417-439) becomes a two-edged sword and the duke has to honor it though he does not like the outcome. To maintain the stability and trustworthiness of such law, the enforcement personnel or institution will have to guard the interests of all, of those parties the people like and those they detest, if justice is to be kept throughout the state. But as the incident develops, Shylock is not given preeminent privileges in his claim. It has been pointed out that Shylock's case entails the conflict between the common law court and the court of chancery. Simply put, the concept of equity and equity right of redemption takes precedent over the narrow common law, bonds and contract (Spinosa 1993: 65-85). Shylock's claim will be rebuffed by Portia disguised as a defender for Antonio. What the case comes down is that the failure of a business transaction or loan cannot be transferred to be a mere revenge that bears no one good. It has to be defused and annulled. Economic activities that are counter-productive need to be satirized particularly when hatred of class, gender or race is involved. But if Antonio's business has high risks, so does Shylock's and it may end up as forfeiture in the court of chancery.

Both Antonio and Shylock try to guard their own interests that involve the social or rather economic class. The malfunctioning of their practice in any link or phase will cost dearly if not total destruction because it portends systemic problem. Yet there are purely individual attempts in the economic structure that rebounds and harms whoever holds a greedy appetite. Such is the case of Ben Jonson's Volpone, dramatized to denote moral degeneration and anxiety on poverty. In fact, Jonson was very concerned about the principles of morality and justice that England was stepping into while he began his playwriting. Jonson witnessed moral corruption as London became more cosmopolitan, playing a more important role in commerce and vouching voracious competition in the early seventeenth century. Both Shylock (1.3.143) and Volpone (Volpone 1.1.87) satirically speak of "kindness" as a means to accessing wealth. But the intention of Volpone is more a trap than a test. In his game, Volpone lays out the plot to attract the ambitious:

I have no wife, no parent, child, ally

To give my substance to, but whom I make

Must be my heir, and this makes men observe me.

This draws new clients daily to my house, 
Women and men of every sex and age,

That bring me presents, send me plate, coin, jewels, With hope that when I die - which they expect

Each greedy minute - it shall then return

Tenfold upon them; whilst some, covetous

Above the rest, seek to engross me whole,

And counterwork, the one unto the other,

Contend in gifts as they would seem in love. (1.1.73-84)

Pretending to look for an heir so as to cheat the greedy to lavish on him gifts and attention, Volpone seeks more wealth than he needs. The activity he engages in does not involve labor or industrial production, nor packaging, circulating, or delivery of products but simply uses speculative means to divert other people's wealth into his pocket. Unlike Antonio or Shylock, Volpone has "nothing to sell,/ little or nothing to sell" (2.2.75-76). Rather than providing financial assistance to the needy, he has all interested parties harmed through fraud and wile. Regardless of which social status the victims belong, they all become prey to Volpone's plot: Voltore, a lawyer, is tricked to offer a gold plate (1.3.10), Corbaccio, an old gentleman brings in a bag of gold coins (1.4.68), Corvino, a merchant, competes the bid with a pearl (1.5.6) and a diamond (1.5.17). Such gifts come in so easily that Volpone thinks it "better than rob churches" (1.5.91). But to the victims, Volpone's success testifies "what a rare punishment/ Is avarice to itself!" (1.4.142-143).

But the loss of riches due to deception is only the material loss. There is also the moral degradation of the dignified knight who tarnishes the reputation of his wife Lady Would-be and the merchant Corvino who intends to sell out his beautiful wife in order to become the heir of Volpone. The latter case in particular corrupts his soul and ruins his marriage though cuckoldry and marriage vows do not seem to bother him. Celia, Corvino's wife, becomes no more than a commodity that can be dispensed of and a wife has been degenerated to become a trade-in product so that Volpone blatantly says,

[...] Celia, he that would sell thee

Only for hope of gain, and that uncertain

He would have sold his part of paradise

For ready money, had he met a copeman. (3.7.141-144)

By means of hoax and libel, Volpone's resourceful servant Mosca traps Bonario, son of Corbaccio, into believing the set-up that Corbaccio will disinherit him (3.2.43-44). All the crafty and complicated turnings of events are made real because most characters in the play are eyeing for the opportunity to inherit 
SO

Volpone who has no offspring. To be able to receive a legacy without earning for it is a boon that guarantees a pleasurable life without travail. It is a sign of grace and emotional uplifting that causes the beneficiary no sweat or induces no hard labor except application of speculation and treachery. With no tax incurred and practically no investment risks, legacy from inheritance is a fast way of accumulating capital regardless of one's effort, or "the highway to get riches" (5.12.99). Indeed, all parties concerned in the scenario intend to make fast return of yields either through deception or speculation. Naturally, integrity has been forsaken to adopt a corrupting life of shamefulness and avarice. In their obsession of scheming for riches people are turning against one another and commonwealth has been taken over by opportunism. Instead of generating and promoting proper activities to increase resources beneficial to social wellbeing, the fraudulent tactics prove to be counter-productive to human relationship and economic viability. Ironically, those who seek after unjust riches turn out to be poorer and become losers not to mention tarnishing their moral character. In brief, by addressing the economic concerns of various individuals the play magnifies the moral power of literary writings in keeping with the model of Utopia.

Altogether the three works selected manifest three modes of economic activities that bespeak the contemporary experience of the English society. The first mode portrays altruism in an ideal situation, making it a classic model for the authentic type of communism where everyone helps everyone else and lives in a bountiful society. It is a world of dreamland where egalitarianism replaces privileges and monopolies. The economy is seen closely tied up to political structure that mandates the vision and outcome of social behaviors. The second mode builds on legal obligation rather than mutual trust as a guarantor of fairness and protection. Yet one witnesses the fearful consequence of commercial contracts based on legal bind. Insecurity brings in self-consciousness and self-protective measures so much so that vengeful mood leads to hilarious and disastrous results. Foreign trade and shipping complications reveal greatly the mentality and anxiety of the English in late sixteenth century. Economic contribution and gains have often to pay a price that causes frustration and stressful obsession. While the first mode implements a naturally stabilized society and a welfare state, the second mode emulates the first but social classes and politico-economic cleavage sets in though it may present a more realistic social picture than the first one. Legal means rather than being a protective code can be manipulated to accommodate the schemers to become an accomplice of the oppressive party when it deals with the capital market instead of the labor market. Until that manipulation 
is being outsmarted by a perceptive person, justice may not prevail. As for the third mode, it clearly betrays the norm of egotism, the very opposite of the Utopian world. In principle, the economic dealings of the whole list of upper class people prove to be no more than artful thievery. Individual moral deprivation has thus induced social corruption leading to the degeneration of classes. That is due to over-emphasis on material culture and hedonism at the expense of moral stricture. Individual labor as a means to earn for respect and revenues has all but sacrificed. The notions of unjust inheritance, avarice and the will to cheat in order to gain riches expose the worse of capitalism. The titular hero has indeed appropriately shaped up an eponymous dubbing Volpone, the fox.

\author{
Francis K. H. So \\ francs@kmu.edu.tw; francs@mail.nsysu.edu.tw \\ Kaohsiung Medical University \\ 100, Shih-Chuan $1^{\text {st }}$ Road \\ Sanmin District, Kaohsiung 807 \\ TAIWAN, R.O.C.
}

\title{
Bibliography
}

Bourdieu, P. 1986. The Forms of Capital. - J. Richardson, ed., Handbook of Theory and Research for the Sociology of Education. New York: Greenwood, 241-258.

Clay, C. G. A. 1984. Economic expansion and social change: England, 1500-1700. Volume One: People, Land, and Towns. Cambridge: Cambridge University Press. Elton, G. R. 1997. England under the Tudors. $3^{\text {rd }}$ ed. London: The Folio Society.

Heard, N. 1992. Tudor Economy and Society. London: Hodder \& Stoughton.

Hodgson, G. M. 1999. Economics and Utopia: Why the Learning Economy is not the End of History. London and New York: Routledge.

Kennard, F.; Hanne, A. 2015. Boom \& Bust: A Look at Economic Bubbles. Raleigh, N. C.: Lulu.com.

More, T. 1965. The Complete Works of St. Thomas More. Volume 4: Utopia. Ed. by E. Surtz S. J. and J. H. Hexter. New Haven: Yale University Press.

Outhwaite, R. B. 1982. Inflation in Tudor and Stuart England. $2^{\text {nd }}$ ed. London and Basingstoke: Macmillan.

Ryner, B. D. 2014. The Cosmopolitical Economies of The Merchant of Venice and A New Way to Pay Old Debts. - Renaissance Drama, 42.2, 141-167, https://wwwjournals-uchicago-edu.ezproxy.lis.nsysu.edu.tw: 9443/doi/full/10.1086/678122 (24.03.2019). 
SO

Slack, P. 1988. Poverty and Policy in Tudor Stuart England. London and New York: Longman.

Sokol, B. J.: Sokol, M. 1999. Shakespeare and the English Equity Jurisdiction: The Merchant of Venice and the Two Texts of King Lear. - The Review of English Studies, 50.200, 417-439, https://www-jstor-org.ezproxy.lis.nsysu.edu.tw:9443/ stable/517390?seq=1\#metadata_info_tab_contents (24.03.2019).

Spinosa, C. 1993. Shylock and Debt and Contract in "The Merchant of Venice". Cardozo Studies in Law and Literature, 5.1, 65-85, https://www-jstor-org.ezproxy. lis.nsysu.edu.tw:9443/stable/743393\#metadata_info_tab_contents (24.03.2019). 